\title{
Identification of sources of resistance to anthracnose stalk rot in maize
}

\author{
Identificação de fontes de resistência à antracnose do colmo do milho
}

\begin{abstract}
Alessandro Nicoli ${ }^{I}$ Laércio Zambolim ${ }^{\mathrm{I}}$ Rodrigo Veras da Costa ${ }^{\mathrm{II}}$ Lauro José Moreira Guimarães ${ }^{\mathrm{II}}$ Fabrício Eustáquio Lanza ${ }^{I}$ Dagma Dionísia da SilvaII Luciano Viana Cota ${ }^{I^{*}}$
\end{abstract}

\section{ABSTRACT}

Adoption of resistant cultivars is the primary measure used to control anthracnose stalk rot. The goal of this study was to identify maize-resistant genotypes to anthracnose stalk rot, which are similar to the hybrid 2B710. Experiments were performed at Embrapa Maize and Sorghum experimental fields in Brazil. The first experimental trial evaluated 234 maize lines as well as two commercials hybrids, BRS1010 (susceptible) and 2 B710 (resistant). Artificial inoculations were performed with a strain at the blister (R2) phase, and evaluation of disease severity was performed after 30 days. The second experimental trial evaluated 48 maize lines and hybrids, inoculated with two Colletotrichum graminicola strains. In the first trial, eight resistance groups were formed, and the last lines were more resistant, as was the hybrid $2 B 710$, with values between $11.50 \%$ and $23.0 \%$ of severity. In the second trial, there was an interaction between the two factors, lines and isolates, and the lines often showed the same reaction features as those obtained in the first trial. However, the disease severity was higher for most lines, even when using other isolates. These lines with effective levels of resistance could be used in future studies of inheritance, in programs to develop hybrids, and to identify molecular markers associated with resistance to anthracnose stalk rot in maize.

Key words: Zea mays, germplasm bank, Colletotrichum graminicola.

RESUMO

O uso de cultivares resistentes é a principal medida para o manejo da antracnose do colmo em milho. Neste trabalho, objetivou-se identificar linhagens com niveis de resistência à antracnose do colmo, similar ao híbrido 2B710, considerado resistente. Dois experimentos foram conduzidos na Embrapa Milho e Sorgo. No primeiro experimento, foram avaliados 234 linhagens $e$ os híbridos BRS1010 (suscetivel) e $2 B 710$ (resistente). Foi realizada inoculação artificial com um isolado de $\boldsymbol{C}$. graminicola, na fase de pré-pendoamento e, após 30 dias, foi realizada a avaliação da severidade da antracnose no colmo. O segundo experimento foi conduzido com 48 linhagens e os híbridos inoculados com dois isolados de C. graminicola. No primeiro experimento, os genótipos formaram oito grupos com base na severidade da doença e as linhagens do último grupo foram consideradas as mais resistentes, incluindo o híbrido 2B710, em que os genótipos apresentaram valores de severidade entre 11,50 a 23\%. No segundo experimento, houve interação entre os fatores linhagens e isolados e, de modo geral, as linhagens apresentaram a mesma tendência de reação obtida no primeiro experimento, no entanto, a severidade da doença foi maior para a maioria das linhagens, mesmo quando utilizado o outro isolado. Com isso, foi possivel realizar a seleção de linhagens com bons niveis de resistência, as quais podem ser utilizadas em programas de melhoramento, em estudos de herança, desenvolvimento de híbridos e identificação de marcadores moleculares, associados com resistência à antracnose do colmo.

Palavras-chave: Zea mays, banco de germoplasma, Colletotrichum graminicola.

\section{INTRODUCTION}

Anthracnose stalk rot, caused by Colletotrichum graminicola (Ces.) Wils., is found in maize worldwide. It is the principal disease of maize, capable of causing plant lodging, early plant death, and losses of approximately $35 \%$ in grain weight (BERGSTROM \& NICHOLSON, 1999; DENTI \& REIS, 2003; PALAVERSIC et al., 2009; COSTA et al., 2010a; JIRAK-PETERSON \& ESKER, 2011; COTA et al., 2012).

Characteristic symptoms of anthracnose stalk rot are narrow and longitudinal lesions that

IDepartamento de Fitopatologia, Universidade Federal de Viçosa (UFV), Viçosa, MG, Brasil

IEmbrapa Milho e Sorgo, CP 151, 35701-970, Sete Lagoas, MG, Brasil. E-mail: luciano.cota@embrapa.br. "Corresponding author. Received 07.22.15 Approved 05.30.16 Returned by the author 08.01.16 CR-2015-1052.R2 
have a wet aspect and are brown to reddish in color, while old lesions are typically dark brown to black in color. In the stalk tissues, it is possible to see typical dark-brown coloring, which corresponds to necrotic lesions that lead to plant lodging and early death (BERGSTROM \& NICHOLSON, 1999; COTA et al., 2012).

This disease is one of the most important in maize crops and is very hard to control necessitating the use of integrated management practices. These include crop rotation, incorporation of residues in the soil, balanced fertilization (especially in the case of nitrogen and potassium), correct plant spacing, and control of stalk insect pests such as Sugarcane Borer (Diatrea saccharalis Fabr.) and European corn borer (Ostrinia nubilalis Hübner) (BERGSTROM \& NICHOLSON, 1999; OLIVEIRA et al., 2004; COTA et al., 2015).

However, currently, the main strategy to control anthracnose stalk rot remains the adoption of resistant genotypes: a practice considered both economically viable and environmentally friendly. Resistant cultivars carry genes with resistance to stalk rot infection, which are transferred via a quantitative inheritance mode, with the predominance of an additive genetic effect (CARSON \& HOOKER, 1981; BADU-APRAKU et al., 1987; TOMAN \& WHITE, 1993; BERGSTROM \& NICHOLSON, 1999; PALAVERSIC et al., 2009; MATIELLO et al., 2012). Maize genotypes showing different levels of anthracnose stalk rot resistance have been described in germplasm banks; examples of such genotypes are the following: MP305, DE811ASR (JUNG et al., 1994, BROGLIE et al., 2006; FREY et al., 2011); DW1035 (TOMAM \& WHITE, 1993); A556, A638, Oh43, R177 (CARSON \& HOOKER, 1981); RD6502 (BADU-APRAKU et al., 1987); Bc19064 (PALAVERSIC et al., 2009); CML52 (CHUNG et al., 2011); Das2, Das64 (MATIELLO et al., 2012); H8664 (MATIELLO et al., 2013); 2B710 (GARDINGO, 2008; COSTA et al., 2010b; COTA et al., 2010; CARVALHO et al., 2013). However, in practice, the resistance levels of these genotypes remain weak, and information on effective resistance sources is lacking.

Thus, identifying sources of resistance to anthracnose stalk rot by genotype selection in a germplasm bank can help develop more resistant hybrids, inform studies of resistance inheritance, lead to identification of molecular markers for anthracnose stalk rot resistance genes, and have applications for maker-assisted selection. However, this kind of study is only possible with a germplasm bank, which offers a great range of genetic variability for testing. Hence, the objective of this study was to identify lines resistant to anthracnose stalk rot in the Embrapa Maize and Sorghum germplasm bank.

\section{MATERIALS AND METHODS}

Trials were performed in the experimental fields of Embrapa Maize and Sorghum, located in Sete Lagoas, state of Minas Gerais, Brazil (latitude: 19²8'03" S, longitude: $44^{\circ} 15^{\prime} 08^{\prime}$ "W; elevation: $732 \mathrm{~m}$ ).

The first experimental trial tested 234 maize genotypes from a germplasm bank (Banco de Germoplasma - BAG of Embrapa Maize and Sorghum). Also included in this trial were two positive controls, the commercial hybrids BRS1010 (Embrapa) and 2B710 (Dow Agroscience), which were used as susceptible and resistant genotypes, respectively. The experimental design consisted of randomized blocks with three replications, each formed by one row of $2 \mathrm{~m}$ that was $0.8 \mathrm{~m}$ from others rows, with five plants per meter.

The plant inoculations in the first experimental trial used the single spore strain $C g 03.09$ of $\boldsymbol{C}$. graminicola, following COSTA et al. (2014). The inoculations were performed at the pre-tassel stage using the methods of a sterile toothpick dipped in the spore suspension $\left(10^{6}\right.$ conidiaml $\left.^{-1}\right)$. Before inoculation, the lower leaves from the healthier plants in the plots were removed, exposing the lower nodes, and thereafter, the superficial disinfestation of lower nodes was performed using a solution of $70 \%$ alcohol. Inoculation was made in the third internode, which was perforated using a sterilized manual perforator followed by insertion of the sterilized toothpick immersed in the spore solution. Toothpick was kept in the internode until the evaluation (COSTA et al., 2010b; COTA et al., 2010).

Crop fertilization at the time of planting was done by administering $300 \mathrm{~kg} \cdot \mathrm{ha}^{-1}$ of NPK $(8: 28: 16+0.4 \% \mathrm{Zn})$ and two urea applications $(100 \mathrm{~kg}$. $\left.\mathrm{ha}^{-1}\right)$ on the $15^{\text {th }}$ and $30^{\text {th }}$ day after planting. To control weeds, Atrazine (3L a.i.ha ${ }^{-1}$ ) and Nicosulfuron $(140 \mathrm{~g}$ a.i.ha $\left.{ }^{-1}\right)$ were applied 25 days after planting. The insecticide Spinosad (100mL.ha $\left.{ }^{-1}\right)$ was applied 40 days after planting to control the fall armyworm (Spodoptera frugiperda). Whenever necessary, the trials were irrigated according to soil status demand.

In order to conduct the evaluation, the inoculated and non-inoculated stalks were harvested 30 days after inoculation. Stalks were longitudinally cut and the severity of stalk rot was evaluated by comparing the inoculated internode to a severity scale 
developed by NICOLI et al. (2015). The severity data were first checked to meet ANOVA assumptions: data normality was checked using the KolmogorovSmirnov test and variance homogeneity using the Bartlett test (at $5 \%$ of probability, in the MINITAB 14 software program). Data normality was not met, and so values were subjected to angular transformation according to DINIZ et al. (2006). Subsequently, the ANOVA was performed, and the means were compared by the Scott-Knott test at a 5\% level of probability using the GENES program (CRUZ, 2006).

The second experimental trial used 48 genotypes selected from the first trial and the same two commercial hybrids. Inoculation process was made using two single spore strains $(C g 05.07$ and $C g 03.09)$ of $\boldsymbol{C}$. graminicola, the first $(C g 05.07)$ being more aggressive than the second $(C g 03.09)$ according to COSTA at al. (2014). This was done to ensure the resistance of a genotype to different strains, as there can be variation in severity related to different isolates (WHITE et al., 1987; COSTA at al., 2014).

This trial was conducted in a randomized block design, and the treatments were applied in a factorial $50 \times 2$ arrangement (50 genotypes $\times 2$ strains), with three replicates. The plots were formed by one row of $2 \mathrm{~m}$ that was spaced $0.8 \mathrm{~m}$ apart from other rows, with five plants per meter. The crop management, inoculation, and subsequent evaluation of stalk rot severity followed the procedures described for the first trial. The data were subjected to ANOVA and, where necessary, the means were compared using the Scott-Knott test using a 5\% level of probability in the GENES program (CRUZ, 2006).

\section{RESULTS AND DISCUSSION}

In the first trial, a significant difference was observed among the lines $(P<0.05)$, which formed eight groups according to a means test (Table 1). The genotypes in the first group (A) were the most susceptible, whereas the genotypes in the last group (H) were considered the most resistant because they had the lowest disease severity values. There were 22 genotypes in the group A, showing severity values between $82 \%$ and $92 \%$, including the commercial hybrid BRS1010. For the other groups, there were 29 genotypes in B, 33 in C, 23 in D, 41 in E, 20 in F, 31 in $\mathrm{G}$, and 35 lines in $\mathrm{H}$, which included the resistant hybrid 2B710 (Table 1). The most resistant lines and the resistant hybrid 2B710 had severity values between $11.5 \%$ and $23.0 \%$ to form the last group, $H$.

In the second trial, there was a significant interaction among lines and the $\boldsymbol{C}$. graminicola strain $(P<0.05)$, indicating that the lines showed severity levels that were dependent on one specific strain (Table 2). According to COSTA at al. (2014), there are different races, pathotypes, and haplotypes of C. graminicola in maize that are spread across the regions of Brazil. In general, the strains tended to show the same reaction as that obtained in the first

Table 1 - Groups of severity levels of the anthracnose stalk rot in maize formed by Scott-Knott test $(P<0.05)$, containing 234 lines and two hybrids (BRS 1010 and 2B710).

\begin{tabular}{ll}
\hline Groups $^{\mathrm{a}}$ & \\
\hline A & L1, L2, L3, L4, L5, L6, L7, L8, L9, L10, L11, BRS1010, L13, L14, L15, L16, L17, L18, L19, L20, L21, L22, L23 \\
B & L24, L25, L26, L27, L28, L29, L30, L31, L32, L33, L34, L35, L36, L37, L38, L39, L40, L41, L42, L43, L44, L45, L46, \\
& L47, L48, L49, L50, L51, L52 \\
C & L53, L54, L55, L56, L57, L58, L59, L60, L61, L62, L63, L64, L65, L66, L67, L68, L69, L70, L71, L72, L73, L74, L75, \\
& L76, L77, L78, L79, L80, L81, L82, L83, L84, L85 \\
D & L86, L87, L88, L89, L90, L91, L92, L93, L94, L95, L96, L97, L98, L99, L100, L101, L102, L103, L104, L105, L106, \\
& L107, L108 \\
E & L109, L110, L111, L112, L113, L114, L115, L116, L117, L118, L119, L120, L121, L122, L123, L124, L125, L126, \\
& L127, L128, L129, L130, L131, L132, L133, L134, L135, L136, L137, L138, L139, L140, L141, L142, L143, L144, \\
F & L150, L151, L152, L153, L154, L155, L156, L157, L158, L159, L160, L161, L162, L163, L164, L165, L166, L167, \\
& L168, L169 \\
G & L170, L171, L172, L173, L174, L175, L176, L177, L178, L179, L180, L181, L182, L183, L184, L185, L186, L187, \\
& L188, L189, L190, L191, L192, L193, L194, L195, L196, L197, L198, L199, L200 \\
H & L201, L202, L203, L204, L205, L206, L207, L208, L209, L210, L211, L212, L213, L214, L215, L216, L217, L218, \\
& L219, L220, L221, L222, L223, L224, L225, L226, L227, L228, L229, L230, L231, L232, L233, L234, 2B710, L236 \\
\hline
\end{tabular}

${ }^{\mathrm{a}} \mathrm{A}-$ genotypes with average severity levels of 82.13 to $92.13 \%$; $\mathrm{B}-72.13$ to $80.47 \%$; $\mathrm{C}-62.47$ to $71.30 \%$; $\mathrm{D}-52.97$ to $62.13 \%$; $\mathrm{E}-$ 41.30 to $51.13 \%$; $\mathrm{F}-34.63$ to $40.47 \%$; $\mathrm{G}-23.80$ to $32.97 \%$; $\mathrm{H}-11.43$ to $22.97 \%$. 
Table 2 - Severity levels of anthracnose stalk rot in 48 maize lines and two hybrids (BRS1010 and 2B710), inoculated with two Colletotrichum graminicola strains (Cg03.09 and Cg05.07).

\begin{tabular}{|c|c|c|}
\hline \multirow{2}{*}{ Lines } & Cg03.09 & $\mathrm{Cg} 05.07$ \\
\hline & Severity $(\%)^{*}$ & Severity $(\%)^{*}$ \\
\hline L16 & $92.97 \mathrm{~A} \mathrm{a}$ & $87.97 \mathrm{~B} \mathrm{~b}$ \\
\hline L11 & $92.97 \mathrm{~A} \mathrm{a}$ & $90.47 \mathrm{~B}$ a \\
\hline L1 & $92.97 \mathrm{~A} \mathrm{a}$ & $93.80 \mathrm{~A} \mathrm{a}$ \\
\hline L9 & $92.13 \mathrm{~A} \mathrm{a}$ & $82.13 \mathrm{Cb}$ \\
\hline L22 & $92.13 \mathrm{~A} \mathrm{a}$ & $84.63 \mathrm{C} \mathrm{b}$ \\
\hline BRS 1010 & $90.47 \mathrm{~A} \mathrm{a}$ & $92.97 \mathrm{~A} \mathrm{a}$ \\
\hline L50 & $90.47 \mathrm{~A} \mathrm{a}$ & $93.80 \mathrm{~A} \mathrm{a}$ \\
\hline L32 & $83.80 \mathrm{~B} \mathrm{a}$ & $75.47 \mathrm{D} \mathrm{b}$ \\
\hline L28 & $82.13 \mathrm{~B} \mathrm{~b}$ & $91.30 \mathrm{~B}$ a \\
\hline L67 & $81.30 \mathrm{~B} \mathrm{a}$ & $84.63 \mathrm{C} \mathrm{a}$ \\
\hline L54 & $81.30 \mathrm{~B} \mathrm{a}$ & $85.47 \mathrm{C} \mathrm{a}$ \\
\hline L47 & $81.30 \mathrm{~B} \mathrm{a}$ & $83.80 \mathrm{C} \mathrm{a}$ \\
\hline L55 & $80.47 \mathrm{~B}$ a & $81.30 \mathrm{C} \mathrm{a}$ \\
\hline L102 & $80.47 \mathrm{~B}$ a & $71.30 \mathrm{E} \mathrm{b}$ \\
\hline L75 & $77.97 \mathrm{~B} \mathrm{a}$ & $80.47 \mathrm{D}$ a \\
\hline L78 & $77.12 \mathrm{~B} \mathrm{~b}$ & $83.80 \mathrm{C} \mathrm{a}$ \\
\hline L98 & $72.13 \mathrm{C} \mathrm{b}$ & $77.97 \mathrm{D}$ a \\
\hline L108 & $69.63 \mathrm{C} \mathrm{a}$ & $65.47 \mathrm{~F} \mathrm{a}$ \\
\hline L66 & $68.80 \mathrm{C} \mathrm{b}$ & $88.80 \mathrm{~B} \mathrm{a}$ \\
\hline L90 & $67.97 \mathrm{C} \mathrm{a}$ & $70.47 \mathrm{E} \mathrm{a}$ \\
\hline L153 & $63.80 \mathrm{D}$ a & $56.30 \mathrm{G} \mathrm{b}$ \\
\hline L84 & $62.97 \mathrm{D} \mathrm{b}$ & $79.63 \mathrm{D}$ a \\
\hline L136 & $57.13 \mathrm{E} \mathrm{a}$ & $55.47 \mathrm{G} \mathrm{a}$ \\
\hline L162 & $52.97 \mathrm{~F} \mathrm{a}$ & $46.30 \mathrm{H} \mathrm{b}$ \\
\hline L154 & $48.80 \mathrm{~F} \mathrm{a}$ & $49.63 \mathrm{H} \mathrm{a}$ \\
\hline L151 & $44.63 \mathrm{G} \mathrm{a}$ & $47.13 \mathrm{H} \mathrm{a}$ \\
\hline L186 & $42.13 \mathrm{G} \mathrm{b}$ & $47.13 \mathrm{H} \mathrm{a}$ \\
\hline L183 & $40.47 \mathrm{G} \mathrm{a}$ & $41.30 \mathrm{I} \mathrm{a}$ \\
\hline L204 & $37.97 \mathrm{H} \mathrm{a}$ & $41.30 \mathrm{I}$ a \\
\hline L202 & $35.47 \mathrm{H} \mathrm{a}$ & $38.80 \mathrm{I}$ a \\
\hline L206 & $32.97 \mathrm{I} \mathrm{a}$ & $32.13 \mathrm{~J} \mathrm{a}$ \\
\hline L205 & $32.13 \mathrm{I} \mathrm{b}$ & $38.80 \mathrm{I}$ a \\
\hline L193 & $30.47 \mathrm{I}$ a & $33.80 \mathrm{~J} \mathrm{a}$ \\
\hline L208 & $30.47 \mathrm{I}$ a & $27.97 \mathrm{~K} \mathrm{a}$ \\
\hline L211 & $29.63 \mathrm{I} \mathrm{a}$ & $32.97 \mathrm{~J} \mathrm{a}$ \\
\hline L232 & $29.63 \mathrm{I}$ a & $22.97 \mathrm{~L} \mathrm{~b}$ \\
\hline L219 & $28.80 \mathrm{I}$ a & $30.47 \mathrm{~J} \mathrm{a}$ \\
\hline L220 & $27.97 \mathrm{I}$ a & $29.63 \mathrm{~K} \mathrm{a}$ \\
\hline L227 & $27.97 \mathrm{I} \mathrm{b}$ & $32.97 \mathrm{~J} \mathrm{a}$ \\
\hline L222 & $26.30 \mathrm{I} \mathrm{b}$ & $31.30 \mathrm{~J} \mathrm{a}$ \\
\hline L234 & $23.80 \mathrm{~J} \mathrm{~b}$ & $29.63 \mathrm{~K} \mathrm{a}$ \\
\hline L209 & $23.80 \mathrm{~J} \mathrm{~b}$ & $29.63 \mathrm{~K} \mathrm{a}$ \\
\hline L225 & $23.80 \mathrm{~J} \mathrm{~b}$ & $28.80 \mathrm{~K} \mathrm{a}$ \\
\hline L224 & $22.97 \mathrm{~J} \mathrm{~b}$ & $27.97 \mathrm{~K} \mathrm{a}$ \\
\hline L22 1 & $22.97 \mathrm{~J} \mathrm{~b}$ & $32.13 \mathrm{~J} \mathrm{a}$ \\
\hline L228 & $22.97 \mathrm{~J} \mathrm{~b}$ & $28.80 \mathrm{~K} \mathrm{a}$ \\
\hline $2 \mathrm{~B} 710$ & $22.13 \mathrm{~J} \mathrm{~b}$ & $37.13 \mathrm{~J} \mathrm{a}$ \\
\hline L216 & $22.13 \mathrm{~J} \mathrm{~b}$ & $30.47 \mathrm{~J} \mathrm{a}$ \\
\hline L231 & $21.30 \mathrm{~J} \mathrm{~b}$ & $27.97 \mathrm{~K} \mathrm{a}$ \\
\hline L236 & $19.63 \mathrm{~J} \mathrm{a}$ & $22.97 \mathrm{~L} \mathrm{a}$ \\
\hline Average & $53.13^{* *}$ & $55.55^{* *}$ \\
\hline
\end{tabular}

${ }^{*}$ Means followed by the same capital letter in the column, and the same lower case letter in the line, does not differ by the Scott-Knott test at $5 \%$ probability. ${ }^{* *}$ Average severity for each strain.

Ciência Rural, v.46, n.11, nov, 2016. 
experimental trial. However, the disease severity was greater in the second experimental trial for most of the strains, even for the aggressive isolate $\mathrm{Cg} 03.09$. For example, the most resistant lines in the first trial (Table 1) showed values $23 \%$ above the severity in the second trial (Table 2), in which higher severity values were observed when using the most aggressive strain Cg05.07. As expected, the hybrid BRS1010 was considered susceptible, showing severity above $90 \%$ for both strains. By contrast, the hybrid 2B 710 was considered resistant, showing a severity of $22.1 \%$ (Table 2) when inoculated with the strain $C g 03.09$, and $37.1 \%$ when inoculated with the strain $C g 05.07$. In a joint analysis of the two trials, it was possible to detect nine lines showing resistance features, namely, L234, L209, L225, L224, L221, L228, L216, L231, and L236. These lines showed the same resistance features as those of the resistant hybrid 2B710.

The evaluation method adopted in the present study was efficient to classify the lines to form different resistance categories to anthracnose stalk rot, as done in many reports (CARSON \& HOOKER, 1981; BADU-APRAKU et al., 1987; TOMAN \& WHITE, 1993; COTA et al., 2010; MATIELLO et al., 2012; COSTA at al., 2014).

According to our results, there are resistance sources in the lines from the germplasm bank with high levels of resistance, which are similar to the levels reported in the commercial resistant hybrid 2B710. In a study performed with landraces, the varieties "branco oito carreiras", "oito carreiras branco", "branco duro canguçú", and "sabuguinho caboroxo" were all effective resistance sources to anthracnose stalk rot, being similar to the resistant hybrid 2B710 (GARDINGO, 2008). Many genotypes showing red pigmentation in their tissues are generally considered resistant to anthracnose stalk rot. The red mark is a kind of background to resistance; though there are some red susceptible genotypes. The simple hybrid 2B710 has an effective resistance level and showed red pigmentation in the stalk surface and leaves veins, which appears in some genotypes due to the production of carotenoids and flavonoids (GARDINGO, 2008; COSTA et al., 2010b; COTA et al., 2010; COTA et al., 2012; CARVALHO et al., 2013). This genotype has been used as a positive control in studies investigating anthracnose stalk rot resistance, as well as for genotype selection in germplasm banks; in addition, this hybrid has shown good agronomic features in many studies (COTA et al., 2012; CARVALHO et al., 2013; ZUCARELI et al., 2013, COSTA et al., 2014).

In the present study, the lines L234, L209, L225，L224，L221，L228，L216，L231, and L236 showed effective resistance levels. Therefore, they can be recommended for introduction and use in anthracnose stalk rot-breeding programs. Moreover, these lines can be used in studies of resistance inheritance and crop yield losses, and for molecular marker identification, associated with the enhancement of maize resistance to anthracnose stalk rot.

\section{ACKNOWLEDGMENT}

The authors thank Conselho Nacional de Desenvolvimento Científico e Tecnológico (CNPQ), Fundação de Amparo à Pesquisa do Estado de Minas Gerais (FAPEMIG) and EMBRAPA Maize and Sorghum for the financial, structural and technical support

\section{REFERENCES}

BADU-APRAKU, B. et al. A Major Gene for Resistance to Anthracnose Stalk Rot in Maize. Phytopathology, v.77, p.957959, 1987. Available from: <https://www.apsnet.org/publications/ phytopathology/backissues/Documents/1987Abstracts/ Phyto77 957.htm>. Accessed: Jul. 4, 2016. doi: 10.1094/ Phyto-77-957.

BERGSTROM, G. C.; NICHOLSON, R. L. The biology of corn anthracnose: knowledge to exploit for improved management. Phytopathology, v.83, p.596-608, 1999. Available from: <http:// apsjournals.apsnet.org/doi/abs/10.1094/PDIS.1999.83.7.596>. Accessed: Jul. 4, 2016. doi: 10.1094/PDIS.1999.83.7.596.

BROGLIE, K. E. et al. E. I. du Pont de Nemours and Company; Pioneer Hi-Bred International, Inc.; University of Delaware United States. Polynucleotides and methods for making plants resistant to fungal pathogens. United States Patent 20060223102, 2006. Available from: <https://patentscope.wipo.int/search/en/detail. jsf?docId=WO2006107931>. Accessed: Jul. 4, 2016.

CARSON, M. L.; HOOKER, A. L. Inheritance of resistance to stalk rot of corn caused by Colletotrichum graminicola. Phytopathology, v.71, p.1190-1196, 1981. Available from: <https://www.apsnet.org/publications/phytopathology/backissues/ Documents/1981Articles/Phyto71n11_1190.PDF>. Accessed: Jul. 4, 2016. doi: 10.1094/Phyto-71-1190.

CARVALHO, D. O. et al. Adubação nitrogenada e potássica na severidade da antracnose em dois cultivares de milho. Revista Ceres, v.60, p.380-387, 2013. Available from: $<$ http://www.scielo. br/pdf/rceres/v60n3/11.pdf $>$. Accessed: Jul. 4, 2016. doi: 10.1590/ S0034-737X2013000300011.

CHUNG, C. L. et al. Targeted discovery of quantitative trait loci for resistance to northern leaf blight and other diseases of maize. Theoretical and Applied Genetics, v.123, p.307-326, 2011. Available from: <http://link.springer.com/article/10.1007 \%2Fs00122-011-1585-9>. Accessed: Jul. 4, 2016. doi: 10.1007/ s00122-011-1585-9.

COSTA, R. V. et al. Incidência de Colletotrichum graminicola em colmos de genótipos de milho. Summa Phytopathologica, v.36, p.122-128, 2010a. Available from: <http://www.scielo.br/pdf/ sp/v36n2/a03v36n2.pdf>. Accessed: Jul. 4, 2016. doi: 10.1590/ S0100-54052010000200003. 
COSTA, R. V. et al. Desenvolvimento de metodologia para inoculação de Colletotrichum graminicola em colmo de milho. Sete Lagoas: Embrapa Milho e Sorgo, 2010b. 8p. (Circular técnica, 139). Available from: $<$ http://www.cnpms.embrapa.br/publicacoes/ publica/2010/circular/Circ_139.pdf>. Accessed: Jul. 4, 2016.

COSTA, R. V. et al. Races of Colletotrichum graminicola pathogenic to maize in Brazil. Crop Protection, v.56, p.44-49, 2014. Available from: <http://www.sciencedirect.com/science/ article/pii/S026121941300238X>. Accessed: Jul. 4, 2016. doi: $10.1016 /$ j.cropro.2013.10.005.

COTA, L. V. et al. Métodos de inoculação de Colletotrichum graminicola em colmo de milho. Sete Lagoas: Embrapa Milho e Sorgo, 2010. 7p. Circular técnica, 137. Available from: <http:// www.cnpms.embrapa.br/publicacoes/publica/2010/circular/ Circ_137.pdf>. Accessed: Jul. 4, 2016.

COTA, L. V. et al. Quantification of yield losses due to anthracnose stalk rot on corn in Brazilian conditions. Journal of Phytopathology, v.160, p.680-684, 2012. Available from: <http:// onlinelibrary.wiley.com/doi/10.1111/jph.12008/pdf>. Accessed: Jul. 4, 2016. doi: 10.1111/jph.12008.

COTA, L. V. et al. Manejo de doenças. In: GALVÃO, J.C.C. et al. (Eds.). Milho: do plantio à colheita. Viçosa: Universidade Federal de Viçosa, 2015. p.294-322.

CRUZ, C. D. Programa genes: estatística experimental. Viçosa MG. Folha de Viçosa, 2006. 382p.

DENTI, E. A.; REIS, E. M. Levantamento de fungos associados às podridões do colmo e quantificação de danos em lavouras de milho do planalto médio gaúcho e dos campos gerais do Paraná. Fitopatologia Brasileira, v.28, p.585-590, 2003. Available from: $<$ http://www.scielo.br/pdf/fb/v28n6/a01v28n6.pdf>. Accessed: Jul. 4, 2016. doi: 10.1590/S0100-41582003000600001.

DINIZ, L. P. et al. Avaliação de produtos alternativos para controle da requeima do tomateiro. Fitopatologia Brasileira, v.31, p.171-179, 2006. Available from: <http://www.scielo.br/pdf/fb/ v31n2/30011.pdf $>$. Accessed: Jul. 4, 2016. doi: 10.1590/S010041582006000200008 .

FREY, T. J. et al. Fitness evaluation of Rcgl, a locus that confers resistance to Colletotrichum graminicola (Ces.) G.W. Wils. Using near-isogenic maize hybrids. Crop Science, v.51, p.1551-1563, 2011. Available from: $<$ https://dl.sciencesocieties.org/publications/ cs/abstracts/51/4/1551>. Accessed: Jul. 4, 2016. doi: 10.2135/ cropsci2010.10.0613.

GARDINGO, D. A. Potencial de resistência de variedades crioulas de milho à infecção artificial por Colletotrichum graminicola (Ces.) Wils. Ponta Grossa:(OTCC), Universidade Estadual de Ponta Grossa - Setor de Ciências Agrárias e de Tecnologia, (2008). 36p.

JIRAK-PETERSON, J. C.; ESKER, P. D. Tillage, crop rotation, and hybrid effects on residue and corn anthracnose occurrence in Wisconsin. Plant Disease, v.95, p.601-610, 2011. Available from: <http://apsjournals.apsnet.org/doi/abs/10.1094/PDIS-11-100837>. Accessed: Jul. 4, 2016. doi: 10.1094/PDIS-11-10-0837.

JUNG, M. et al. Generation-means analysis and quantitative trait locus mapping of anthracnose stalk rot genes in maize. Theoretical and Applied Genetics, v.89, p.413-418, 1994. Available from: $<$ http://link.springer.com/article/10.1007\%2FBF00225375>. Accessed: Jul. 4, 2016. doi: 10.1007/BF00225375.

MATIELLO, R. R. et al. Inheritance of resistance to anthracnose stalk rot (Colletotrichum graminicola) in tropical maize inbred lines. Crop Breeding and Applied Biotechnology, v.12, p.179-184, 2012. Available from: <http://www.scielo.br/scielo. php?pid=S1984-70332012000300003\&script $=$ sci_abstract $>$. Accessed: Jul. 4, 2016. doi: 10.1590/S1984-70332012000300003.

MATIELLO, R. R. etal. Comparison of yield damage of tropical maize hybrids caused by anthracnose stalk rot. Tropical Plant Pathology, v.38, p.128-132, 2013. Available from: <http://www.scielo.br/ scielo.php?script=sci_arttext\&pid=S1982-56762013000200006>. Accessed: Jul. 4, 2016. doi: 10.1590/S1982-56762013000200006.

NICOLI, A. et al. Validação de escala diagramática para quantificação da severidade da antracnose do colmo do milho. Ciência Rural, v.45, p.1720-1726, 2015. Available from: $<$ http://www.scielo.br/scielo.php?script=sci_arttext\&pid $=$ S0103-84782015001001720>. Accessed: Jul. 4, 2016. doi: $10.1590 / 0103-8478 \mathrm{cr} 20141510$.

OLIVEIRA, E. et al. Diagnose e controle de doenças na cultura do milho. In: GALVÃO, J. C. C.; MIRANDA, G.V. (Eds.). Tecnologias de produção do milho. Viçosa: Universidade Federal de Viçosa, 2004. p.226-267.

PALAVERSIC, B. et al. Breeding maize for resistance to stalk anthracnose. Maydica, v.54, p.229-232, 2009. Available from: $<$ http:// www.maydica.org/articles/54_229.pdf>. Accessed: Jul. 4, 2016.

TOMAN, J. J.; WHITE, D. G. Inheritance of resistance to anthracnose stalk rot of corn. Phytopathology, v.83, p.981-986, 1993. Available from: <http://www.apsnet.org/publications/ phytopathology/backissues/Documents/1993 Abstracts/ Phyto_83_981.htm>. Accessed: Jul. 4, 2016. doi: 10.1094/ Phyto-83-981.

WHITE, D. G. et al. Variation in pathogenicity, virulence, and aggressiveness of Colletotrichum graminicola on corn. Phytopathology, v.77, p.999-1001, 1987. Available from: $<$ https://www.apsnet.org/publications/phytopathology/ backissues/Documents/1981Articles/Phyto71n10_1080.pdf>. Accessed: Jul. 4, 2016.

ZUCARELI, C. et al. Desempenho agronômico de genótipos de milho de segunda safra na região Norte do Paraná. Scientia Agraria Paranaensis, v.12, p.227-235, 2013. Available from: <e-revista. unioeste.br/index.php/scientiaagraria/article/download/5593/6461>. Accessed: Jul. 4, 2016. doi: 10.18188/1983-1471/sap. v12n3p227-235. 